\title{
GENDER TYPING (PADA ANAK USIA SEKOLAH DASAR)
}

\author{
Asriana Harahap ${ }^{1}$ \\ Dosen Institut Agama Islam Negeri Padangsidimpuan dan Universitas \\ Muhammadiyah Tapanuli Selatan \\ Email: harahapasriana@yahoo.com, harahapasriana3@gmail.com
}

\begin{abstract}
The word gender in Indonesian is borrowed from English. When viewed in a dictionary, there is no clear distinction between sex and gender. Meanwhile, there is no explanation that is able to explain briefly and clearly about the concept of gender and why the concept is important to understand the system of social injustice. In other words, the emergence of obscurity is caused by a lack of explanation about the link between the concept of gender and other issues of injustice. Gender is one of the important aspects that influence social development in the early days of children. Gender terms are intended behavior and attitudes associated with men and women. Most children experience at least three stages in gender development. First, children develop beliefs about gender identity, namely the feeling of men or women. Second, children develop gender privileges, attitudes about which sex they want. Third, they obtain gender provisions, a belief that a person's sex is determined biologically, permanently, and does not change. Although everyone basically assumes that the behavior of children as male or female is caused by an interaction of biological factors and environmental factors, one's view of interaction is not the same for everyone. For some people, this view suggests that certain environmental conditions are needed before the trends previously programmed appear. Culture, schools, peers, the media, and other family members are other sources. However, it is important to keep from shifting too far from this direction because especially in the early years of parental development is an important influence on gender development. According to the theory of cognitive development towards gender, the gender forms of children arise after they develop a concept of gender. When they understand themselves as men or women consistently, children often arrange their world according to gender.
\end{abstract}

Keyword: Typing Gender, Sekolah Dasar.

\section{PENDAHULUAN}

Pada tahun-tahun terakhir ini, perubahan yang paling cepat terjadi pada perkembangan anak-anak terjadi pada area gender. Sementara istilah sex (jenis kelamin) mengacu pada dimensi biologis seseorang sebagai laki-laki atau perempuan dan istilah gender mengacu pada dimensi sosial-budaya seseorang sebagai laki-laki atau perempuan. Sedikit sekali aspek dari perkembangan anak yang lebih mendasari identitas diri mereka dan hubungan sosial mereka daripada masalah gender. Salah satu aspek dari gender melahirkan pernyataan khusus suatu

${ }^{1}$ Penulis adalah dosen Madrasah Ibtidaiyah di Fakultas Tarbiyah dan Ilmu Keguruan, Institut Agama Islam Negeri Padangsidimpuan dan Universitas Muhammadiyah Tapanuli Selatan (HP: 085261307293 alamat email harahapasriana@yahoo.com, harahapasriana3@gmail.com). 
peran gender (gender role) yang merupakan suatu set harapan yang menetapkan bagaimana seharusnya perempuan dan laki-laki berpikir, bertingkah laku, dan berperasaan.

Permasalahan-permasalahan kontroversial banyak beredar di antara kaum laki-laki dan perempuan. Perubahan tersebut masih jauh dari sempurna, namun orang-orang yang melakukan perubahan dibidang sosial berharap bahwa satu generasi lagi dari sekarang, usaha yang telah dilakukan pada decade akhir abad 20 akan mewariskan lebih banyak kebebasan, kesempatan, dan fleksibilitas bagi kaum perempuan. Kemungkinan pada generasi selanjutnya, ketika remaja sekarang menjadi orang dewasa di masa depan, berbagai permasalahan seperti permasalahan gaji, pengasuhan anak, aborsi, pemerkosaan, dan kekerasan rumah tangga tidak lagi dibicarkan sebagai “permasalahan perempuan” tetapi, lebih kepada permasalahan ekonomi, permasalahan keluarga, dan permasalahan etis sebagai cermin dari parmasalahan hak antara kaum perempuan dan laki-laki.

Beberapa aspek perkembangan sosial anak-anak lebih sentral terhadap identitas mereka dan terhadap relasi sosial mereka daripada terhadap jenis kelamin atau gender mereka.

\section{PEMBAHASAN}

Apa sesungguhnya yang dimaksud dengan gender typing itu? Dari pengamatan, masih terjadi ketidak jelasan, kesalahpahaman tentang apa yang dimaksud dengan konsep gender dan kaitannya dengan usaha emansipasi kaum perempuan. Setidaknya ada beberapa penyebab terjadinya ketidakjelasan tersebut. Kata gender dalam bahasa Indonesia dipinjam dari bahasa Inggris. Kalau dilihat dalam kamus, tidak secara jelas dibedakan pengertian sex dan gender. Sementara itu, belum ada uraian yang mampu menjelaskan secara singkat dan jelas mengenai konsep gender dan mengapa konsep tersebut penting guna memahami sistem ketidak adilan sosial. Dengan kata lain timbulnya ketidakjelasan itu disebabkan oleh kurangnya penjelasan tentang kaitan antara konsep gender dengan masalah ketidakadilan lainnya.2

Anak-anak memahami peran gender lebih luas pada masa kanak-kanak, dan juga identitas gender mereka (pandangan mereka sendiri relatif maskulin atau feminin) juga berubah. Kita akan melihat perkembangan itu berbeda untuk anak laki-laki dan perempuan, dan ini bisa sangat bervariasi antar budaya. 3

Bila jenis kelamin mengacu pada dimensi biologis sebagai laki-laki atau perempuan, maka gender mengacu pada dimensi sosial sebagai laki-laki atau perempuan. Dua aspek gender mengandung sebutan khusus-identitas gender dan peran gender. Identitas gender (gender identity) ialah rasa sebagai laki-laki atau perempuan, yang diperoleh oleh sebagian besar anak-anak pada waktu mereka berusia 3 tahun. Peran gender (gender role) adalah seperangkat harapan menggambarkan bagaimana laki-laki dan perempuan seharusnya berpikir, bertindak, dan merasa. ${ }^{4}$

${ }^{2}$ Mansour Fakih, Analisis Gender dan Transformasi Sosial, (Yogyakarta: Pustaka Pelajar, 1996), hlm. 7.

${ }^{3}$ Laura E. Berk, Development Through the Lifespan, (America: United Stated of America, 2006), hlm. 343.

${ }^{4}$ John W. Santrock, Life-Span Development: Perkembangan Masa Hidup, (Jakarta: Erlangga, 2002), hlm. 280. 
Untuk memahami konsep gender harus dibedakan kata gender dengan kata seks (jenis kelamin). Pengertian jenis kelamin merupakan pensifatan atau pembagian dua jenis kelamin manusia yang ditentukan secara biologis yang melekat pada jenis kelamin tertentu. Misalnya, bahwa manusia jenis laki-laki adalah manusia yang memiliki penis, memiliki jakala (kala menjing) dan memproduksi sperma. Sedangkan perempuan memiliki alat reproduksi seperti Rahim dan saluran untuk melahirkan, memproduksi telur, memiliki vagina, dan mempunyai alat menyusui. Alat-alat tersebut secara biologis melekat pada manusia jenis perempuan dan laki-laki selamanya. Arti secara biologis alat-alat tersebut tidak bisa dipertukarkan antara alat biologis yang melekat pada manusia laki-laki dan perempuan. Secara permanen tidak berubah dan merupakan ketentuan biologis atau sering dikatakan sebagai ketentuan Tuhan atau kodrat.5

Ayat Al-Qur’an tentang makna gender terdapat dalam QS. An-Nahl 16:5859 yang berbunyi.

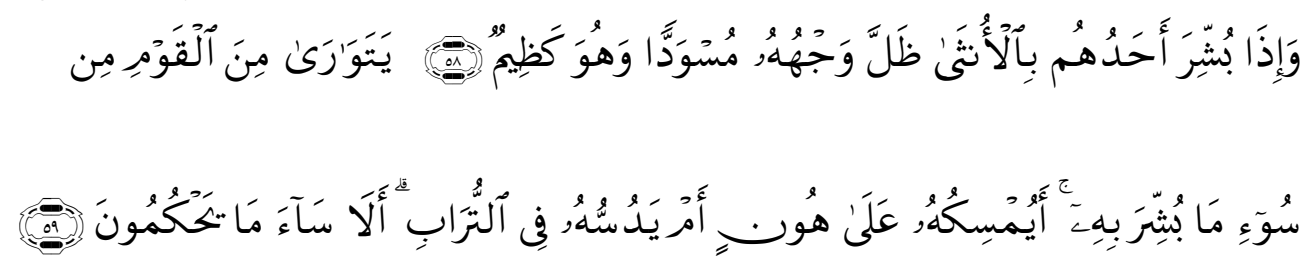

Artinya: "Dan apabila seseorang dari mereka diberi kabar dengan (kelahiran) anak perempuan, hitamlah (merah padamlah) mukanya, dan Dia sangat marah. Ia Menyembunyikan dirinya dari orang banyak, disebabkan buruknya berita yang disampaikan kepadanya. Apakah Dia akan memeliharanya dengan menanggung kehinaan ataukah akan menguburkannya ke dalam tanah (hidup-hidup)?. Ketahuilah, alangkah buruknya apa yang mereka tetapkan itu". ${ }^{6}$

Maksud ayat di atas adalah apabila diberitahukan salah seorang dari mereka bahwa mereka mempunyai anak perempuan dan istri mereka telah melahirkan seorang anak perempuan, merah padam mukanya akibat kekecewaannya. Dalam dadanya penuh rasa marah dan dendam, lalu mereka menyembunyikan diri karena malu dan timbullah dalam pikirannya "Apakah akan dibiarkan anak itu hidup dengan menanggung kehinaan, tidak diberi pusaka dan tidak mendapat layanan yang layak, ataukah dikubur hidup-hidup.

Gender adalah dimensi sosial budaya seseorang sebagai laki-laki ataupun perempuan. Peran gender adalah suatu set harapan yang menetapkan bagaimana perempuan atau laki-laki harus berpikir, bertindak dan berperasaan. ${ }^{7}$ Gender merupakan salah satu aspek penting yang mempengaruhi perkembangan sosial pada masa awal anak-anak. Istilah gender dimaksudkan tingkah laku dan sikap yang diasosiasikan dengan laki-laki dan perempuan. Kebanyakan anak mengalami sekurang-kurangnya tiga tahap dalam perkembangan gender. Pertama, anak mengembangkan kepercayaan tentang indentitas gender, yaitu rasa laki-laki atau perempuan. Kedua, anak mengembangkan keistimewaan gender, sikap tentang

\footnotetext{
${ }^{5}$ Mansour Fakih, Analisis Gender dan ..., hlm. 8.

${ }^{6}$ Departemen Agama RI, Al-Quran dan Terjemahannya, (Semarang: PT. Karya Toha
} Putra, 2002), hlm. 372. 372. 
jenis kelamin mana yang mereka kehendaki. Ketiga, mereka memperoleh ketetapan gender, suatu kepercayaan bahwa jenis kelamin seseorang ditentukan secara biologis, permanen, dan tak berubah-ubah. ${ }^{8}$

Ketiga aspek gender tersebut berperan terhadap pengetahuan umum anak tentang peran gender yang diharapkan masyarakat. Pengetahuan ini sering disebut sebagai peran jenis kelamin atau stereotip gender. Kesadaran tentang stereotip ini telah dimiliki oleh anak-anak prasekolah. Dia sering membicarakannya dan bahkan bertindak menurut cara-cara yang mencerminkan stereotip peran gender tersebut. Stereotip peran gender merujuk pada karakteristik psikologis atau perilaku yang secara tipikal diasosiasikan dengan laki-laki atau perempuan. Anakanak mempelajari stereotip peran gender ini melalui berbagai cara dan pola-pola yang dapat diramalkan. ${ }^{9}$

Tahun 1920-an para peneliti telah menegaskan eksistensi kromosom jenis kelamin manusia, yakni material genetis yang menentukan jenis kelamin kita. Teori Freud dan teori Erikson mempromosikan gagasan bahwa anatomi ialah takdir. Hormon mempengaruhi perkembangan gender, walaupun seringkali tidak sekuat pada binatang. Hermafrodit ialah indvidu yang jenis kelaminnya antara laki-laki dan perempuan karena ketidakseimbangan hormon. Dewasa ini para pakar perkembangan anak semua adalah interaksionis bila pengaruh biologis dan lingkungan terhadap gender diterima. Tetapi interaksi diartikan berbeda oleh orang yang berbeda. ${ }^{10}$

Walaupun setiap orang pada dasarnya menganggap bahwa perilaku anak-anak sebagai laki-laki atau perempuan adalah disebabkan oleh suatu interaksi faktor biologis dan faktor lingkungan, pandangan seseorang interaksionis tidak sama bagi setiap orang. Bagi beberapa orang, pandangan tersebut mengemukakan bahwa kondisi-kondisi lingkungan tertentu diperlukan sebelum kecenderungankecenderungan yang diprogram sebelumnya tampak. Bagi beberapa orang lain, pandangan tersebut mengemukakan bahwa suatu lingkungan tertentu akan memiliki pengaruh yang berbeda bergantung pada kecendrungan-kecenderungan anak. Bagi beberapa yang lain lagi, mengemukakan bahwa anak-anak membentuk lingkungan-lingkungan mereka, termasuk lingkungan interpersonal mereka, dan sebaliknya. Proses-proses pengaruh dan kontra pengaruh terbentang sepanjang masa. Sepanjang perkembangan, laki-laki dan perempuan Secara aktif membangun versi mereka sendri tentang pola-pola perilaku maskulin dan feminin mereka yang dapat diterima. ${ }^{11}$

Dalam kebudayaan kita, orang-orang dewasa membedakan jenis kelamin segera setelah bayi lahir. Perlakuan "merah muda dan biru" dapat diterapkan kepada anak laki-laki dan perempuan sebelum mereka meninggalkan rumah sakit. Segera setelah itu perbedaan-perbedaan dalam gaya potongan rambut, pakaian, dan mainan menjadi tampak jelas. orang-orang dewasa dan teman-teman sebaya memilih perbedaan-perbedaan ini sepanjang perkembangan. Dan anak laki-laki dan perempuan mempelajari peran-peran gender melalui peniruan atau belajar mengobservasi dengan cara menonton apa yg dikatakan dan dilakukan oleh orang lain. Pada tahun-tahun terakhir ini, gagasan bahwa orangtua adalah pelaku

${ }^{8}$ Desmita, Psikologi Perkembangan, (Bandung: PT Remaja Rosdakarya, 2008), hlm. 146.

${ }^{9}$ Ibid, hlm. 147.

10 John W. Santrock, Life-Span Development: Perkembangan Masa Hidup, (Jakarta: Erlangga, 2002), hlm. 280.

${ }^{11}$ John W. Santrock, Life-Span Development: Perkembangan Masa Hidup..., hlm. 281. 
sosialisasi yang penting dalam perkembangan peran gender dikecam. Orangtua hanyalah salah satu dari sekian banyak sumber tempat individu mempelajari peran-peran gender. Kebudayaan, sekolah, teman-teman sebaya, media, dan anggota-anggota keluarga lain adalah sumber-sumber lain. Namun demikian adalah penting untuk menjaga agar tidak bergeser terlalu jauh dari arah ini karena khususnya pada tahun-tahun awal perkembangan orangtua adalah pengaruh yang penting bagi perkembangan gender. ${ }^{12}$

1. Teori identifikasi dan teori belajar social

Dua teori terkemuka memutuskan perhatiannya pada cara anak-anak memperoleh sikap dan perilaku maskulin dan feminin dari orangtua mereka. Teori identifikasi (identifikasi theory) berasal dari pandangan Freud bahwa anak-anak prasekolah mengembangkan suatu daya tarik seksual kepada orangtua yang berbeda jenis kelamin, kemudian pada usia kira-kira 5 atau 6 tahun meninggalkan daya tarik ini karena perasaan-perasaan cemas, dan sesudah itu mengidentifikasikan diri dengan orang tua yang berjenis kelamin sama. Tetapi dewasa ini banyak pakar perkembangan anak tidak yakin perkembangan gender bergerak maju atas dasar identifkasi, setidak-tidaknya bukan menurut penekanan Freud atas dasar daya tarik seksual pada masa anak-anak. Anak-anak dikaruniai jenis gender tertentu jauh lebih awal dari usia 5 atau 6 tahun, dan mereka menjadi maskulin dan feminin bahkan bila orangtua yang berjenis kelamin sama tidak ada di keluarga itu. ${ }^{13}$

2. Teori belajar sosial tentang gender (Social Learning Theory Of Gender)

Menekankan bahwa perkembangan gender anak-anak terjadi melalui observasi dan peniruan perilaku gender, dan melalui mekanisme hadiah dan hukuman anak-anak mengalami perilaku gender yang sesuai dan tidak sesuai. Tidak seperti teori identifikasi, teori belajar sosial berpendapat bahwa daya tarik seksual terhadap orangtua tidak berkaitan dengan perkembangan gender. Orangtua seringkali menggunakan hadiah dan hukuman untuk mengajarkan anak perempuan mereka agar bersikap dan berperilaku feminim (Rina, kamu gadis baik kalau kamu main bonekamu dengan manis) dan maskulin (Agus, anak laki-laki sebesar kamu tidak boleh menangis). Teman-teman sebaya juga secara ekstensif menghadiahi dan menghukum perilaku gender. Dan dengan mengobservasi orangorang dewasa dan teman-teman sebaya di rumah, di sekolah, di tetangga, dan di televisi, anak-anak terbuka secara luas terhadap banyak sekali model yang memperlihatkan perilaku maskulin dan feminin. Pengkritik pandangan belajar sosial berpendapat bahwa perkembangan gender tidak sepasif yang ditunjukkan. Kita akan mendiskusikan pandangan-pandangan kognitif terhadap perkembangan gender pada bagian berikut, yang menekankan bahwa anak-anak membangun secara aktif dunia gender mereka.

a. Pengaruh Pengasuhan

Orangtua melalui tindakan dan melalui contoh mempengaruhi perkembangan gender anak-anak mereka. Ibu dan ayah secara psikologis adalah penting bagi perkembangan gender anak-anak. Ibu-ibu secara lebih konsisten diberi tanggungjawab atas pengasuhan dan perawatan fisik, ayah lebih cenderung terlibat dalam interaksi yang bersifat permainan dan diberi tanggungjawab untuk menjamin bahwa anak laki-laki dan anak perempuan menyesuaikan diri dengan norma-norma kebudayaan yang ada. Dana apakah ayah lebih atau tidak lebih

\footnotetext{
12 John W. Santrock, Life-Span Development: Perkembangan Masa Hidup..., hlm. 282.

${ }^{13}$ John W. Santrock, Life-Span Development: Perkembangan Masa Hidup..., hlm. 283.
} 
berpengaruh terhadap anak-anak, yang pasti adalah bahwa ayah lebih terlibat dalam pensosialisasian anak laki-laki daripada anak perempuan. Ayah memainkan suatu bagian yang sangat penting di dalam perkembangan peran gender mereka lebih cenderung daripada ibu-ibu untuk bertindak berbeda terhadap anak laki-laki dan perempuan dan dengan demikian memberi banyak sumbangan bagi perbedaan di antara gender. ${ }^{14}$

Sejauh ini, kita telah membicarakan berbagai pengaruh biologis dan sosial terhadap perkembangan gender remaja. Teori kognitif menekankan bahwa remaja membentuk dunia gender mereka sendiri secara aktif. Pada bagian ini, kita akan melihat dua teori kognitif, yaitu teori perkembangan kognitif terhadap gender dan teori skema gender.

Menurut teori perkembangan kognitif terhadap gender, bentuk gender anakanak muncul setelah mereka mengembangkan suatu konsep tentang gender. Pada saat mereka memahami diri mereka sebagai laki-laki atau perempuan secara konsisten, anak-anak sering menyusun dunianya berdasarkan gender. ${ }^{15}$ Berdasarkan teori Piaget dan pertama kali dicetuskan oleh ahli perkembangan Lawrence Kohlberg, teori perkembangan kognitif terhadap gender dimulai dengan cara berikut: anak perempuan berpendapat, "saya seorang perempuan. Saya ingin melakukan pekerjaan-pekerjaan perempuan, oleh karena itu kesempatan untuk melakukan hal-hal tersebut sangat berharga. Setelah diperoleh kemampuan untuk mengkategorikan, anak-anak berusaha mencapai kekonsistenan dalam menggunakan kategori-kategori tersebut dalam perilaku mereka sehari-hari. ${ }^{16}$

Teori perkembangan kognitif Kolhberg menekankan bahwa perubahan penting dalam perkembangan gender muncul di masa kanak-kanak. Pada tahap konkrit operasional anak-anak mengerti kepastian gender di mana seorang lakilaki tetap seorang laki-laki tanpa peduli apakah ia mengenakan celana atau rok, atau apakah rambutnya pendek atau panjang. ${ }^{17}$

Pada umumnya anak usia 2 tahun sudah dapat menerapkan label laki-laki atau perempuan secara tepat atas dirinya sendiri dan orang lain. Meskipun demikian, pada usia ini anak belum memahami ketetapan gender (gender constancy). Konsepnya tentang gender lebih didasarkan pada ciri-ciri fisik, seperti pakaian, model rambut atau jenis permainan. Pada umumnya anak-anak baru mencapai ketetapan gender pada usia 7 hingga 9 tahun. ${ }^{18}$

Ketika konsep mereka tentang ketetapan gender terbentuk dengan jelas, anakanak kemudian akan termotifikasi untuk menjadi seorang laki-laki atau perempuan yang sejati. Karena itu, dia akan meniru model-model perilaku dari jenis kelamin yang sama. Berikut ini akan dijelaskan dua tren penting dari perkembangan gender pada masa awal anak-anak, yaitu: ${ }^{19}$

b. Permainan dan Aktivitas

Perkembangan gender pada masa awal anak-anak dapat dilihat dari permainan dan aktifitas yang dilakukannya. Anak-anak usia antara 2 dan 3 tahun, telah mempelajari stereotip gender konvensional yang dihubungkan dengan berbagai aktivitas dan objek-objek umum. Mereka menghubungkan gender

\footnotetext{
14 John W. Santrock, Life-Span Development: Perkembangan Masa Hidup..., hlm. 283.

${ }^{15}$ John W. Santrock, Adolescence Perkembangan Remaja..., hlm. 370.

${ }^{16}$ John W. Santrock, Adolescence Perkembangan Remaja..., hlm. 371.

${ }^{17}$ John W. Santrock, Adolescence Perkembangan Remaja..., hlm. 372.

${ }^{18}$ Desmita, Psikologi Perkembangan..., hlm. 147.

${ }^{19}$ Desmita, Psikologi Perkembangan..., hlm. 147.
} 
dengan mainan, seperti permainan mobil-mobilan adalah "untuk anak laki-laki” dan boneka "untuk anak perempuan". Pada saat yang sama, mereka belajar mengasosiasikan jenis pakaian (rok untuk perempuan dan celana panjang untuk laki-laki), peralatan-peralatan umum (gergaji untuk laki-laki dan pengkocok telur untuk perempuan), dan pemainan-permainan umum (permainan kaleng untuk laki-laki dan permainan memasak/boneka untuk perempuan).

Pada awal usia sekolah, mereka mulai menghubungkan keluarga dan pekerjaan tertentu dengan gender, sekalipun keluarga mereka tidak memperlihatkan pembagian tersebut. Mereka percaya bahwa perempuan tinggal di rumah untuk mengasuh anak-anak dan mengerus rumah tangga, sedangkan lakilaki pergi ke luar untuk bekerja. Karena itu, tidak heran kalau anak sering mengasosiasikan perawat adalah perempuan dan pilot adalah laki-laki.

Di dalam berbagai situasi, anak-anak yang muda belia memperkuat stereotip gender dengan memilih mainan dan aktivitas yang dihubungkan dengan jenis kelamin mereka. Dalam kenyataannya, banyak anak yang benar-benar tidak mau bermain dengan permainan yang secara tegas mereka asosiasikan dengan gender lain. Terutama anak laki-laki, menunjukkan sesuatu kecenderungan untuk tidak mengakui sesuatu apapun yang berhubungan dengan perempuan dalam hidupnya, seperti menolak permainan boneka sebab itu adalah "permainan anak perempuan”. Tetapi, anak perempuan kelihatannya sedikit ekstrim untuk bermainmain dengan truk dan balok ketimbang anak laki-laki yang bermain-main dengan dandanan pakaian. ${ }^{20}$

\section{c. Kualitas Personal}

Berbeda dengan permainan dan aktivitas, anak-anak prasekolah mengembangkan stereotip gender tentang kualitas pribadi relatif lebih lambat. Baru pada usia kira-kira 5 tahun anak-anak mulai mengetahui gender mana yang dianggap lembut, tenang dan lemah. Pengetahuan semacam ini terus berkembang sepanjang masa anak-anak dan remaja.

Belakangan ini, diusulkan teori gender skema (gender schema theory) untuk menjelaskan perkembangan pemahaman anak mengenai gender. Skema adalah suatu struktur kognitif, yakni suatu jaringan asosiasi yang mengorganisir dan memandu persepsi-persepsi individu. Skema gender adalah mengorganisir dunia dalam sudut pandang perempuan dan laki-laki. Teori skema gender adalah pernyataan bahwa perhatian dan perilaku individu dipadu oleh motivasi internal untuk menyesuaikan diri dengan standar-standar dan stereotip-stereotip sosial budaya yang berbasis gender.

Dengan demikian dapat dipahami bahwa teori skema gender merupakan suatu bentuk kepercayaan dan stereotip tentang gender yang digunakan anak untuk mengorganisir informasi tentang karakteristik, pengalaman, dan harapan dari hubungan gender. Teori skema gender menganjurkan bahwa "penentuan gender" terjadi ketika individu siap untuk mengkodekan dan mengorganisir informsi sesuai dengan apa yang dipandang tepat atau khas bagi laki-laki atau bagi perempuan dalam suatu masyarakat.

\footnotetext{
${ }^{20}$ Desmita, Psikologi Perkembangan..., hlm. 148.
} 
Pemikiran skema gender seorang anak berkembang melalui serangkaian tahap. Pertama, seorang anak mempelajari suatu hal yang secara langsung dihubungkan dengan masing-masing jenis kelamin, seperti, "anak laki-laki bermain dengan mobil” dan "anak perempuan bermain dengan boneka”. Kedua, sekitar usia empat hingga 6 tahun, anak mulai mengembangkan asosiasi yang lebih kompleks dan tidak langsung terdapat informasi yang relevan atau jenis kelaminnya sendiri, tetapi tidak untuk lawan jenis. Ketiga, pada usia kira-kira 8 tahun anak juga mempelajari asosiasi yang relevan terhadap lawan jenis dan telah menguasai konsep gender kewanitaan (femininity) dan laki-laki (masculinity). ${ }^{21}$

d. Faktor gender dan teman bermain

Dalam kegiatan bermain sosial (social play) anak cenderung memilih teman bermain yang dapat diajak kerja sama dan saling pengertian. Pemilihan teman bermain dimulai dari dalam kehidupan keluarga kemudian berubah pemilihan teman di luar keluarga. Anak-anak usia bawah tiga tahun mulai bermain bersama orangtua atau saudara-saudara kandungnya, tapi menginjak usia 4-5 tahun anak mulai memilih teman bermain di luar keluarganya. Anak mulai membuka wawasan pergaulan dan belajar mengembangkan kemampuan kerjasama dengan anak-anak sebaya yang lain. Selain itu, anak usia bawah tiga tahun cenderung belum menyadari atau melihat gender dalam kegiatan bermain. Mereka mau bersedia bermain dengan siapapun baik laki-laki atau wanita. Mereka tidak mempedulikan jenis kelamin, tapi untuk anak usia 4-5 tahun sudah mulai mempertimbangkan jenis kelamin sebagai teman bermain. ${ }^{22}$

e. Ketimpangan Gender

Isu kesetaraan gender muncul dari menguatnya kesadaran publik bahwa telah terjadi ketimpangan antara laki-laki dan perempuan pada penyelenggaraan kehidupan bersama. Ketimpangan ini tidak saja ada di negara-negara berkembang, namun telah menjadi sebuah fenomena global. ${ }^{23}$ Salah satu riset yang mampu menunjukkan ketimpangan yang terjadi di masyarakat Barat adalah riset yang dilakukan oleh Mino Vianello dkk. Yang diterbitkan dalam buku Gender Inequality, dalam penelitiannya Vianello menemukan bahwa kesenjangan dan kesetimpangan tersebut dibentuk oleh berbagai hal, di antaranya adalah pemahaman perbedaan sex dan nilai-nilai dalam masyaraka. Faktor-faktor ini menjadi faktor penyebab yang bersifat umum.

Dari uraian sebelumnya dapat dengan jelas dibedakan antara perbedaan jenis kelamin (seks) dengan perbedaan gender. Dalam kondisi saat ini masih menunjukkan bahwa perbedaan jenis kelamin dapat menimbulkan perbedaan gender (gender differences) di mana kaum perempuan itu tidak rasional, emosional, dan lemah lembut sedangkan laki-laki memiliki sifat rasional, kuat dan perkasa.

Gender differences (perbedaan gender) sebenarnya bukan suatu masalah sepanjang tidak menimbulkan gender inequalities (ketidakadilan gender). Namun yang menjadi masalah adalah ternyata gender differences ini telah menimbulkan berbagai ketidakadilan, baik bagi kaum laki-laki dan utamanya bagi kaum perempuan. Secara biologis (kodrat) kaum perempuan dengan organ

\footnotetext{
${ }^{21}$ Desmita, Psikologi Perkembangan..., hlm. 149.

${ }^{22}$ Agoes Dariyo, Psikologi Perkembangan, (Bandung: PT Refika Aditama, 2011), hlm. 231.

${ }^{23}$ Riant Nugroho, Gender dan Administrasi Publik, (Yogyakarta: Pustaka Pelajar, 2008), hlm. 39.
} 
reproduksinya dapat hamil, melahirkan, dan menyusui kemudian muncul gender role (peran gender) sebagai perawat, pengasuh, dan pendidik anak. Dengan demikian gender role dianggap tidak menimbulkan masalah dan tidak perlu digugat. Namun yang menjadi masalah dan perlu dipertanyakan adalah struktur gender inequalities yang timbul oleh gender role dan gender differences. ${ }^{24}$

Gender inequalities (ketidakadilan gender) merupakan sistem dan struktur di mana kaum laki-laki dan perempuan menjadi korban dari sistem tersebut. Dengan demikian agar dapat memahami perbedaan gender yang menyebabkan ketidakadilan maka dapat dilihat dari berbagai manifestasinya, yaitu sebagai berikut:

Marginalisasi. Sesungguhnya, timbul kemiskinan yang terjadi dalam masyarakat dan negara merupakan sebab akibat dari proses marginalisasi yang menimpa kaum laki-laki dan perempuan yang disebabkan oleh berbagai kejadian, antara lain penggusuran, bencana alam atau proses eksploitasi. Bentuk marginalisasi yang paling dominan terjadi terhadap kaum perempuan yang disebabkan oleh gender. Meskipun tidak setiap bentuk marginalisasi perempuan disebabkan oleh gender inequalities (ketidakadilan gender), namun yang dipermasalahkan di sini adalah bentuk marginalisasi yang disebabkan oleh gender differenced (perbedaan gender). ${ }^{25}$

Gender differences ini disebagai akibat dari beberapa perbedaan jenis dan bentuk, tempat dan waktu, serta mekanisme dari proses marginalisasi kaum perempuan. Gender differences ini bila ditinjau dari sumbernya dapat berasal dari kebijakan pemerintah, keyakinan, tafsir agama, keyakinan tradisi dan kebiasaan atau bahkan asumsi ilmu pengetahuan. Misalnya, program pertanian green revolution (revolusi hijau) yang hanya memfokuskan petani laki-laki sehingga secara ekonomis menyebabkan banyak perempuan desa tersingkir dan menjadi miskin. Hal ini disebabkan karena ada asumsi bahwa petani itu identik dengan jenis kelamin laki-laki sehingga banyak petani perempuan yang tersingkir dari sawah. Kemudian adanya program kredit untuk petani yang artinya petani yang berjenis kelamin laki-laki, serta adanya pelatihan bagi petani laki-laki. Hal ini mengakibatkan banyak kaum perempuan miskin di desa termarginalisasi, yakni semakin miskin dan tersingkir karena tidak mendapat pekerjaan di sawah. Ini berarti bahwa program green revolution dirancang tanpa melalui pertimbangan aspek gender.

Bentuk marginalisasi terhadap kaum perempuan juga terjadi dalam rumah tangga, masyarakat atau kultur dan bahkan negara, jika tidak hanya terjadi di tempat pekerjaan. Di dalam rumah tangga, marginalisasi terhadap perempuan sudah terjadi dalam bentuk diskriminasi atas anggota keluarga yang laki-laki dan perempuan. Timbulnya proses marginalisasi ini juga diperkuat oleh tafsir keagamaan maupun adat istiadat. Misalnya, pemberian hak waris di dalam sebagai tafsir keagamaan porsi untuk laki-laki dan perempuan berbeda, di mana pembagian hak waris untuk laki-laki lebih besar dari perempuan.

Subordinasi. Subordinasi timbul sebagai akibat pandangan gender terhadap kaum perempuan. Sikap yang menempatkan perempuan pada posisi yang tidak penting muncul dari adanya anggapan bahwa perempuan itu emosional atau

\footnotetext{
${ }^{24}$ Riant Nugroho, Gender dan Administrasi Publik..., hlm. 40.

${ }^{25}$ Riant Nugroho, Gender dan Administrasi Publik..., hlm. 41.
} 
irasional sehingga perempuan tidak bisa tampil memimpin merupakan bentuk dari subordinasi yang dimaksud. ${ }^{26}$

Proses subordinasi yang disebabkan karena gender terjadi dalam segala macam bentuk dan mekanisme yang berbeda dari waktu ke waktu dan dari tempat ke tempat. Dalam hidup di masyarakat, rumah tangga, dan bernegara, banyak kebijakan yang dikeluarkan tanpa menganggap penting kaum perempuan. misalnya, adanya peraturan yang dikeluarkan pemerintah yaitu jika suami akan pergi belajar (jauh dari keluarga) dapat mengambil keputusan sendiri sedangkan bagi istri harus dapat seizin suami. Dalam rumah tangga misalnya, dalam kondisi keuangan rumah tangga yang terbatas masih sering terdengar adanya prioritas untuk bersekolah bagi laki-laki di banding perempuan, karena ada anggapan bahwa perempuan tidak perlu sekolah tinggi-tinggi, namun demikian pada akhirnya nanti akan masuk ke dapur juga. Hal seperti ini sesungguhnya muncul dari kesadaran gender yang tidak adil.

Stereotip. Pelabelan atau penandaan negatif terhadap kelompok atau jenis kelamin tertentu, secara umum dinamakan stereotip. Akibat dari stereotip ini biasanya timbul diskriminasi dari berbagai ketidakadilan. Salah satu bentuk stereotip ini adalah yang bersumber dari pandangan gender. Banyak sekali bentuk stereotip yang terjadi di masyarakat yang diletakkan kepada umumnya kaum perempuan sehingga berakibat menyulitkan, membatasi, memiskinkan, dan merugikan kaum perempuan.

Misalnya, adanya keyakinan di masyarakat bahwa laki-laki adalah pencari nafkah, maka setiap pekerjaan yang dilakukan oleh perempuan dinilai hanya sebagai tambahan saja sehingga pekerjaan perempuan boleh saja dibayar lebih rendah dibandingkan laki-laki. Kemudian adanya anggapan di masyarakat bahwa perempuan bersolek biasanya dilakukan dalam rangka memancing perhatian lawan jenis, sehingga pada kasus kekerasan maupun pelecehan seksual hal ini selalu dikaitkan bahkan perempuan sebagai korban yang disalahkan. Selain itu, ada juga anggapan dari masyarakat yang melihat bahwa tugas perempuan adalah melayani suami. Stereotip seperti ini memang suatu hal yang wajar, namun berakibat pada menomorduakan pendidikan bagi kaum perempuan. Stereotip pada contoh tersebut dapat terjadi di mana-mana.

Keyakinan stereotip gender. Selama tahun-tahun sekolah, anak-anak memperluas keyakinan stereotip gender yang didapat pada masa kanak-kanak. Penelitian di banyak negara mengungkapkan bahwa stereotip ciri kepribadian dalam lipatan dengan mantap, menyerupai orang dewasa sekitar usia 11 tahun (yang terbaik, 2001: Heyman \& Legare, 2004). Misalnya, anak-anak menganggap "tangguh," "agresif," "terukur," "dominan" seperti wanita (serbin, powlishta, \& Gulko, 1993). ${ }^{27}$

Anak-anak memperoleh perbedaan ini dari mengamati perbedaan jenis kelamin dalam perilaku dan juga perlakuan orang dewasa. Orang dewasa, misalnya, cenderung menuntut kemandirian yang lebih besar dari anak laki-laki. Saat membantu anak dengan suatu tugas, orang tua (terutama ayah) berperilaku lebih berorientasi penguasaan dengan anak laki-laki, menetapkan standar yang lebih tinggi, menjelaskan konsep, dan menunjukkan fitur penting dari tugas-tugas - terutama selama kegiatan mengetik gender, seperti kegiatan sains. Selanjutnya,

\footnotetext{
${ }^{26}$ Riant Nugroho, Gender dan Administrasi Publik..., hlm. 42.

${ }^{27}$ Laura E. Berk, Development Through the Lifespan..., hlm. 343.
} 
orang tua kurang sering mendorong anak perempuan untuk mengambil keputusan sendiri. Dan kedua orang tua dan guru lebih sering memuji anak laki-laki karena pengetahuan dan prestasi, anak perempuan karena ketaatan. ${ }^{28}$

Violence (kekerasan) merupakan assault (invasi) atau serangan terhadap fisik maupun integritas mental psikologis seseorang yang dilakukan terhadap jenis kelamin tertentu, umumnya perempuan sebagai akibat dari perbedaan gender. Bentuk dari kekerasan ini seperti pemerkosaan dan pemukulan hingga pada bentuk yang lebih halus lagi, seperti seksual harassment (pelecehan seksual) dan penciptaan ketergantungan. Violence terhadap perempuan banyak sekali terjadi karena stereotip gender. Pemerkosaan yang merupakan salah satu violence yang sering kali terjadi sebenarnya disebabkan bukan karena unsur kecantikan melainkan karena kekuasaan dan stereotip gender yang diletakkan kepada kaum perempuan. Gender violence pada dasarnya disebabkan karena ketidaksetaraan kekuatan yang ada dalam masyarakat. Violence yang disebabkan oleh bias gender ini disebut gender-relate violence.

Identitas dan perilaku gender. Identitas gender laki-laki dan perempuan mengikuti jalur yang berbeda di masa kecil. Dari kelas tiga sampai enam, anak laki-laki memperkuat identifikasi mereka dengan ciri kepribadian "maskulin", sedangkan identifikasi anak perempuan dengan ciri "feminin". Anak perempuan mulai menggambarkan diri mereka memiliki karakteristik "jenis kelamin lainnya". Sementara anak laki-laki biasanya berpegang pada pencarian "maskulin", anak perempuan sekarang bereksperimen dengan pilihan yang lebih luas. Selain memasak, menjahit, dan mengasuh anak, mereka bergabung dengan tim olahraga terorganisir dan mengerjakan proyek sains. Anak perempuan, lebih sering daripada anak laki-laki, mempertimbangkan peran kerja masa depan yang stereotip untuk jenis kelamin lainnya, seperti petugas pemadam kebakaran dan astronom. $^{29}$

Seiring anak-anak usia sekolah mencirikan diri mereka sendiri dalam hal disposisi umum, identitas gender mereka diperluas untuk mencakup evaluasi diri berikut, yang sangat mempengaruhi penyesuaian mereka:

1. Jenis kelamin biasanya - tingkat di mana anak merasa serupa dengan orang lain dari jenis kelamin yang sama. Meskipun anak-anak tidak perlu diketik jenis kelamin untuk menganggap diri mereka khas gender, namun kesejahteraan psikologis mereka bergantung pada perasaan bahwa mereka "cocok" dengan teman seks mereka yang sama.

2. Kesetaraan gender - sejauh mana anak merasa puas dengan tugas gendernya, yang juga mempromosikan kebahagiaan.

3. Merasa tekanan untuk menyesuaikan diri dengan peran gender - sejauh mana anak merasa menjadi orang tua dan tidak menyetujui ciri-ciri gendernya. Karena tekanan seperti itu mengurangi kemungkinan anak-anak akan mengeksplorasi pilihan yang berkaitan dengan minat dan bakat mereka, anakanak yang merasa tekanan dengan mengetik gender sangat sering tertekan. ${ }^{30}$

\section{KESIMPULAN}

\footnotetext{
${ }^{28}$ Laura E. Berk, Development Through the Lifespan..., hlm. 343.

${ }^{29}$ Laura E. Berk, Development Through the Lifespan..., hlm. 344.

${ }^{30}$ Laura E. Berk, Development Through the Lifespan..., hlm. 344.
} 
1. Kata gender dalam bahasa Indonesia dipinjam dari bahasa Inggris. Kalau dilihat dalam kamus, tidak secara jelas dibedakan pengertian sex dan gender. Sementara itu, belum ada uraian yang mampu menjelaskan secara singkat dan jelas mengenai konsep gender dan mengapa konsep tersebut penting guna memahami sistem ketidak adilan sosial. Dengan kata lain timbulnya ketidakjelasan itu disesbabkan oleh kurangnya penjelasan tentang kaitan antara konsep gender dengan masalah ketidakadilan lainnya.

2. Gender merupakan salah satu aspek penting yang mempengaruhi perkembangan sosial pada masa awal anak-anak. Istilah gender dimaksudkan tingkah laku dan sikap yang diasosiasikan dengan laki-laki dan perempuan. Kebanyakan anak mengalami sekurang-kurangnya tiga tahap dalam perkembangan gender. Pertama, anak mengembangkan kepercayaan tentang indentitas gender, yaitu rasa laki-laki atau perempuan. Kedua, anak mengembangkan keistimewaan gender, sikap tentang jenis kelamin mana yang mereka kehendaki. Ketiga, mereka memperoleh ketetapan gender, suatu kepercayaan bahwa jenis kelamin seseorang ditentukan secara biologis, permanen, dan tak berubah-ubah.

3. Walaupun setiap orang pada dasarnya menganggap bahwa perilaku anak-anak sebagai laki-laki atau perempuan adalah disebabkan oleh suatu interaksi faktor biologis dan faktor lingkungan, pandangan seseorang interaksionis tidak sama bagi setiap orang. Bagi beberapa orang, pandangan tersebut mengemukakan bahwa kondisi-kondisi lingkungan tertentu diperlukan sebelum kecenderungan-kecenderungan yang diprogram sebelumnya tampak. Kebudayaan, sekolah, teman-teman sebaya, media, dan anggota-anggota keluarga lain adalah sumber-sumber lain. Namun demikian adalah penting untuk menjaga agar tidak bergeser terlalu jauh dari arah ini karena khususnya pada tahun-tahun awal perkembangan orangtua adalah pengaruh yang penting bagi perkembangan gender. Menurut teori perkembangan kognitif terhadap gender, bentuk gender anak-anak muncul setelah mereka mengembangkan suatu konsep tentang gender. Pada saat mereka memahami diri mereka sebagai laki-laki atau perempuan secara konsisten, anak-anak sering menyusun dunianya berdasarkan gender.

\section{DAFTRA PUSTAKA}

Dariyo, Agoes, Psikologi Perkembangan, Bandung: PT Refika Aditama, 2011.

Departemen Agama RI, Al-Quran dan Terjemahannya, Semarang: PT. Karya Toha Putra, 2002.

Desmita, Psikologi Perkembangan, Bandung: PT Remaja Rosdakarya, 2008.

E. Berk, Laura, Development Through the Lifespan, America: United Stated of America, 2006.

Fakih, Mansour, Analisis Gender dan Transformasi Sosial, Yogyakarta: Pustaka Pelajar, 1996.

Nugroho, Riant, Gender dan Administrasi Publik, Yogyakarta: Pustaka Pelajar, 2008.

Santrock, John W, Adolescence Perkembangan Remaja, Jakarta: Erlangga, 2003.

Santrock, John W. Life-Span Development: Perkembangan Masa Hidup, Jakarta: Erlangga, 2002. 
Al-Muaddib : Jurnal Ilmu-Ilmu Sosial \& Keislaman http://jurnal.um-tapsel.ac.id/index.php/al-muaddib/ issn online : 2549-0427 | issn cetak : 2528-2492 Volume 1 Nomor 2 ( Januari-Juni) 2019 